\title{
Immunogenicity and antigenicity of a recombinant chimeric protein containing epitopes of poliovirus type 1
}

\author{
X.-X. PAN ${ }^{1}$, J. WANG ${ }^{2}$, W.-Y. XIA ${ }^{2}$, X.-F. LI ${ }^{1}$, L.-J. YANG ${ }^{1}$, C. HUANG ${ }^{1}$, Y.-D. CHEN²
}

\begin{abstract}
${ }^{1}$ Key Laboratory of Chemistry in Ethnic Medicinal Resources, State Ethnic Affairs Commission and Ministry of Education, Yunnan Minzu University, Yunnan, 650500, P. R. China; ${ }^{2}$ Yunnan Key Laboratory of Vaccine Research and Development on Severe Infectious Diseases, Institute of Medical Biology, Chinese Academy of Medical Sciences and Peking Union Medical College, Yunnan, 650118, P. R. China
\end{abstract}

Received December 14, 2015; revised January 13, 2016; accepted May 31, 2016

\begin{abstract}
Summary. - To design a vaccine that simultaneously prevents both rotavirus (RV) and poliovirus (PV), a PV type 1 (PV1) chimeric protein using RV VP6 as a vector (VP6F) was constructed, expressed in Escherichia coli expression system and characterized by SDS-PAGE, Western blot, immunofluorescence assay and neutralization test. The results showed that the chimeric protein reacted with anti-VP6F and anti-PV1 antibodies and elicited production of serum antibodies against the chimeric protein in guinea pigs. Antibodies against the chimeric protein neutralized RV Wa and PV1 infection in vitro. The results provided a relevant possibility of developing novel approaches in the rational design of vaccines effective against both RV and PV.
\end{abstract}

Keywords: chimeric protein; neutralizing activity; rotavirus; poliovirus epitope

\section{Introduction}

Group A rotavirus (RVA), belonging to the Reoviridae family, is the most important etiologic agent of acute gastroenteritis in infants and young children worldwide, and responsible for 453, 000 deaths annually, primarily in developing countries (Parashar et al., 2006; Tate et al., 2012). Significant reduction of RV hospitalizations has been observed in industrialized and developing countries after implementation of oral live RV vaccines, Rotarix and Rotateq. However, lower immunogenicity, efficacy and potential adverse of these vaccines should not be ignored (Cunliffe et al., 2012; Eng et al., 2012; Kollaritsch et al., 2015; Sow et al., 2012). Moreover, the RV vaccines at present are mainly based on the serotype-specific neutralizing antigens VP4 and VP7, which are not sufficient enough to protect against infections from a variety of RV genotypes. VP6, as the group antigen of $\mathrm{RV}$, is the major structural protein forming

*Corresponding author. E-mail: chenyd@imbcams.com.cn; phone: +86-871-68335402.

Abbreviations: $\mathrm{CPE}=$ cytopathic effect; $\mathrm{PV}=$ poliovirus; $\mathrm{RV}=$ rotavirus; TCID $_{50}=50 \%$ tissue culture infectivity doses the middle layer in the triple-layered viral capsid. For the last few years, studies have shown that VP6 could stimulate a protective immune response (Bugli et al., 2014; Li et al., 2014; Marashi et al., 2014; Pastor et al., 2014; Shoja et al., 2015) and a short fragment of VP6 could provide significant reduction in virus infectivity in vitro (El-Senousy et al., 2013). Previous experiments demonstrated that anti-VP6 llama-derived single-chain antibody fragments $(\mathrm{VHH})$ had neutralizing activity against VP6 in vitro (Garaicoechea et al., 2008). Using RV VP6 as a vector (VP6F), the chimeric proteins carrying epitopes derived from the VP4 of RV were constructed and demonstrated that these chimeric proteins had good antigenic reactivity and immunogenicity (Teng et al., 2014).

Poliovirus (PV) (the genus Enterovirus, the Picornaviridae family) is the causative agent of acute paralytic poliomyelitis; and is classified into three serotypes (type 1, type 2, and type 3) (Bannwarth et al., 2015; Hogle and Filman, 1989). WHO and its partners set out in 1988 to eradicate PV by the year 2000 through the effectiveness of vaccination strategies, but in recent years, the virus had staged a comeback and leaped across the border into yet another countries that had been polio-free for years (Chumakov and Ehrenfeld, 2008; Roberts, 2014). Wild PV still remains endemic in Pakistan, 
Afghanistan and Nigeria and during 2014 a total of 359 wild PV cases were detected in nine countries worldwide (Hagan et al., 2015). Together with the emergence of vaccine-derived PV (VDPV) strains and recombinant circulating vaccinederived PV (cVDPVs), the campaign of eradicating PV will have a long way to go.

The neutralizing antigenic structure of PV has been characterized by monoclonal antibodies (Blondel et al., 1986; Diamond et al., 1985; Minor et al., 1983; Page et al., 1988). Three important neutralizing antigenic sites involved in virus neutralization of PV were distributed on surface-exposed loops of structural proteins VP1, VP2, and VP3 (Van der Marel et al., 1983). Neutralizing antigenic site 1, is composed of amino acids 91-102, 254, 168 of VP1; neutralizing antigenic site 2 , is a complex site which includes residues 166-170 and 270 of VP2, and residues 221-226 of VP1; and neutralizing antigenic site 3 is also a complex site which includes residues 285-289 of the VP1, 58-60, 71, 73 of the VP3, and residue 72 of the VP2. The amino acid residues 89 to 100,220 to 222,286 to 290 of the VP1 were important cross neutralizing epitopes (Minor et al., 1986) and could induce cross neutralizing antibody, protecting adults from infections by different PV serotypes (Herremans et al., 2000).

$\mathrm{RV}$ and PV both replicate in intestinal duct and elicit both humoral mucosal responses to viruses with the production of secretory immunoglobulin A (IgA) antibody after natural infection and vaccine immunization (Fiore et al., 1997; Giammarioli et al., 1996; Ogra et al., 1971; Savilahti et al., 1988). Since RV and PV share similar transmission routes, simultaneous prevention of RV and PV has great importance for optimal utilization of the limited resources in developing countries. Some studies showed that PV vaccines were evaluated in co-administration with oral RV vaccines according to the Expanded Program on Immunization (EPI) schedule were proved effective and safe (Steele et al., 2010; Zaman et al., 2009).

In this study, using VP6F, three foreign epitopes derived from PV1 were inserted into the surface loops of VP6F to construct a chimeric protein, and then the chimeric protein was expressed in E. coli BL21 (DE3) cells. The expressed chimeric protein was confirmed by immunoblot and immunofluorescence assay; and was used to immunize guinea pigs to analyze the epitope-specific humoral response. The results obtained in the present study provide a new direction of exploration for the development of vaccines against both RV and PV.

\section{Materials and Methods}

Cells and viruses. MA104 cells (fetal rhesus monkey kidney cells) were grown in Eagle's Minimum Essential medium (MEM; Sigma-Aldrich Inc., USA) supplemented with $10 \%$ fetal bovine serum. Vero cells (African green monkey kidney cells) were grown in Dulbecco's Modified Eagle's medium (DMEM; Sigma-Aldrich Inc., USA) supplemented with 5\% fetal bovine serum. MEM medium (without calf serum) was used when cells were inoculated and cultured with RV or PV. All cells were grown at $37^{\circ} \mathrm{C}$ in a $5 \% \mathrm{CO}_{2}$ atmosphere. The human RV strain Wa (G1P[8]) was maintained at the Institute of Medical Biology, Peking Union Medical College, and adapted to grow in cell culture by serial passages in MA104 cells. Three types of attenuated PV, type 1 Sabin SO+1 (PV1), type 2 Sabin SO+1 (PV2), type 3457 Pfizer RSO1 (PV3) were provided from WHO and adapted in Vero cells.

Preparation of viruses and purification. Confluent cell monolayers were cultivated in Roche bottle $\left(210 \mathrm{~cm}^{2}\right)$ and maintained in MEM medium followed by the infection with the viruses at $37^{\circ} \mathrm{C}$ in an atmosphere of $5 \% \mathrm{CO}_{2}$. When cytopathic effect (CPE) appeared among $\geq 75 \%$ of cells, cells and supernatant were harvested and then frozen, and thawed three times. After centrifugation at 3,000 $\times \mathrm{g}$ at $4^{\circ} \mathrm{C}$ for $30 \mathrm{~min}$, the viral supernatant was collected. For purification of the virus, polyethylene glycol 20000 (PEG 20000; Amresco, USA) to a final concentration of $5 \%(\mathrm{w} / \mathrm{v})$ was added to the viral supernatant and stirred at low speed overnight at $4^{\circ} \mathrm{C}$. The precipitate was collected after centrifugation at $10,000 \times \mathrm{g}$ at $4^{\circ} \mathrm{C}$ for $1 \mathrm{hr}$, and dissolved in 20 volumes of TNMC buffer $(10 \mathrm{mmol} / \mathrm{l}$ Tris- $\mathrm{HCl}$ [pH 7.0], $150 \mathrm{mmol} / \mathrm{l} \mathrm{NaCl}, 1 \mathrm{mmol} / \mathrm{l} \mathrm{MgCl}, 10 \mathrm{mmol} / \mathrm{l} \mathrm{CaCl}_{2}$ ) for 30 $\mathrm{min}$ at room temperature. Then the precipitate was collected after centrifugation at $50,000 \times \mathrm{g}$ at $4^{\circ} \mathrm{C}$ for $1 \mathrm{hr}$, resuspended in TNMC buffer and followed by extraction with equal volume of trifluorotrichloroethane. After centrifugation at $12,000 \times \mathrm{g}$ at $4^{\circ} \mathrm{C}$ for 10 $\mathrm{min}$, the aqueous phase was collected and the organic phase was extracted twice with the $1 / 2$ volume of TNMC buffer. Samples of the aqueous phase were pooled. The virus solution containing $10 \%$ sucrose $(4 \mathrm{ml})$ was placed onto the bottom of the centrifuge tube containing $15 \%$ sucrose cushion $(1 \mathrm{ml})$ and centrifuged at 45,000 $\times \mathrm{g}$ at $4^{\circ} \mathrm{C}$ for $18 \mathrm{hr}$. Fractions of the target virus were collected and dissolved in 20 times the volume of TNMC buffer; then centrifuged at $50,000 \times \mathrm{g}$ at $4^{\circ} \mathrm{C}$ for $1 \mathrm{hr}$. The virus pellet was collected, dissolved in TNMC buffer and stored at $-20^{\circ} \mathrm{C}$.

Virus titration. Determination of infectious titers of strain RV Wa and PV were carried out in MA104 and Vero cells, respectively. Briefly, RV strain Wa was pre-treated with acetylated trypsin $(10 \mu \mathrm{g} /$ $\mathrm{ml}$; Sigma-Aldrich Inc., USA) for $1 \mathrm{hr}$ at $37^{\circ} \mathrm{C}$, viral serial ten-fold dilutions in MEM medium were titrated on confluent cells grown in 96-well microtiter plates using four replicates per dilution (100 $\mu \mathrm{l} /$ well). The plates were incubated in the presence of $5 \% \mathrm{CO}_{2}$, and cells were observed for CPE regularly under microscope. Virus infectivity titer was quantified by estimating the $50 \%$ tissue culture infectivity doses $\left(\mathrm{TCID}_{50}\right)$ and end points were calculated as previously described (Reed and Muench, 1938).

Construction of recombinant plasmid. To construct expression plasmid for chimeric protein, three neutralizing antigenic epitopes derived from the neutralizing antigenic site 1, 2 and 3 of the $\mathrm{PV}$ were selected and inserted into a foreign epitope presenting system based on RV vector protein VP6F (Fig. 1). Three pairs of 


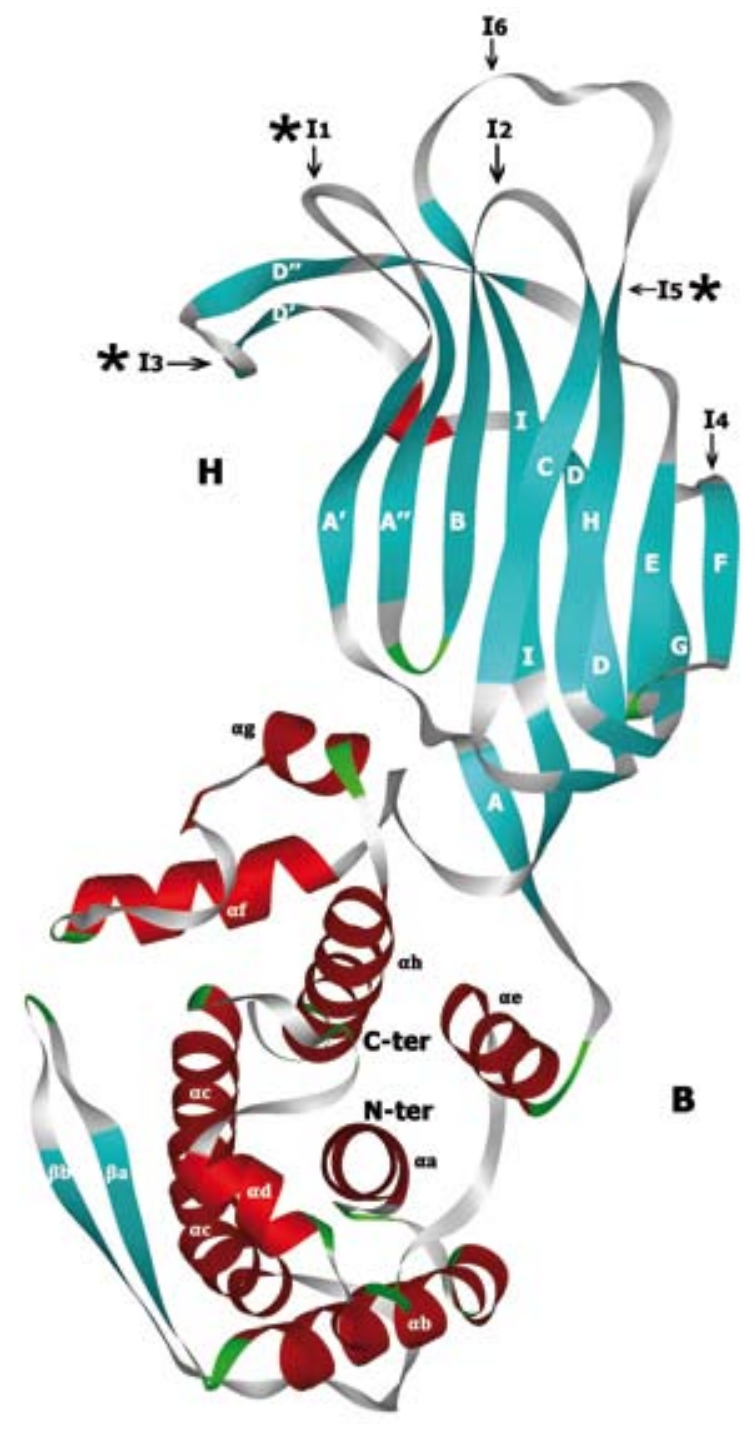

Fig. 1

3D visualization of the VP6F protein as the vector Six foreign epitope insertion sites (I1-I6) on the outer surface that can be chosen for construction of chimeric protein. Sites $\mathrm{I} 1^{*}, \mathrm{I}^{*}$, and $\mathrm{I} 5^{*}$ sites were used for PV1 epitope insertion in this study.

specific oligonucleotide primers for three epitopes of PV1 were designed (Table 1). PV1 strain Mahoney was used as a template for the design of these primers representing the epitopes (Kitamura and Wimmer, 1980). Epitope PV1N1, TVDNPASTTNKDET, corresponded to amino acid residues 91-102, 254, 168 of VP1; epitope PV1N2, QTSPALSAALGD corresponded to amino acid residues 166-170 and 270 of VP2, and residue 221-226 of VP1; and epitope PV1N3, DYKDGSATRSPHTDT corresponded to amino acid residues 285-289 of the VP1, 58-60, 71, 73 of the VP3, and residue 72 of the VP2. The complementary oligonucleotides of each primer pair were annealed and inserted into the corresponding cloning site on the VP6F protein vector, followed
Table 1. Primers used in this study

\begin{tabular}{|c|c|c|}
\hline Epitope & & Primer pair $\left(5^{\prime}-3^{\prime}\right)$ \\
\hline \multirow[t]{2}{*}{ PV1N1 } & Fwl & $\begin{array}{l}\text { GGACCGTGGATAACCCAGCTTCCA } \\
\text { CCACGAATAAGGATGAGCCGC }\end{array}$ \\
\hline & Rev1 & $\begin{array}{l}\text { GGCTCATCCTTATTCGTGGTGGAAGC } \\
\text { TGGGTTATCCACGGTCCGC }\end{array}$ \\
\hline \multirow[t]{2}{*}{ PV1N2 } & Fw2 & $\begin{array}{l}\text { CCAGACATCACCTGCCTTATCGGCA } \\
\text { GCACTAGGTGACGGTAC }\end{array}$ \\
\hline & Rev2 & $\begin{array}{l}\text { CGTCACCTAGTGCTGCCGATAAGGCA } \\
\text { GGTGATGTCTGGGTAC }\end{array}$ \\
\hline \multirow[t]{2}{*}{ PV1N3 } & Fw3 & $\begin{array}{l}\text { CGATTACAAGGATGGTAGTGCCACAC } \\
\text { GGAGTCCACATACAGACACGGAGCT }\end{array}$ \\
\hline & Rev3 & $\begin{array}{l}\text { CCGTGTCTGTAT GTGGACTCCGTG } \\
\text { TGGCACTACCATCCTTGTAATCGAGCT }\end{array}$ \\
\hline
\end{tabular}

by cloning into $\mathrm{NdeI} / \mathrm{BamHI}$ site of the expression plasmid $\mathrm{pETL}$ that was derived from pET-3a (Novagen, USA). The resultant expression plasmids were designated pETP6F and pETP6F/ PV1N123. The pETP6F contained the vector protein VP6F gene; pETP6F/PV1N123 contained the VP6F gene with epitope PV1N1 inserted in SacII site (I5), epitope PV1N2 inserted in KpnI site (I3), and epitope PV1N3 inserted in Sac I site (I1). The recombinant plasmids were verified by restriction endonuclease digestion and DNA sequencing.

Protein expression and purification. The plasmids of pETP6F and pETP6F/PV1N123 were transformed separately into E. coli BL21 (DE3) competent cells (Biovector Co., LTD, China) for expression. The transformed E. coli cells were cultured in Luria-Bertani (LB) medium supplemented with $200 \mu \mathrm{g} / \mathrm{ml}$ of ampicillin, incubated at $37^{\circ} \mathrm{C}$ until reaching absorbance $\mathrm{A}_{600}$ of $0.6-0.8$. Cells were collected by centrifugation and resuspended in lysis buffer $(150 \mathrm{mmol} / \mathrm{l} \mathrm{NaCl}$, $50 \mathrm{mmol} / \mathrm{l}$ Tris [pH 7.5], 5\% glycerol, $1 \%$ Triton X-100, 2 mmol/l EDTA, $0.2 \% \beta$-mercaptoethanol). After sonication and centrifugation, proteins were dissolved in $8 \mathrm{mmol} / \mathrm{l}$ urea and analyzed by $10 \%$ sodium dodecyl sulfate polyacrylamide gel electrophoresis (SDS-PAGE). Purification of the target proteins VP6F and 6F/ PV1N123 were carried out as previously described (Chen et al., 2006), and the protein concentrations were determined using the Lowry's method (Lowry et al., 1951).

Animal immunization. For production of antibodies against chimeric protein, guinea pigs (5-7 weeks of age, about $200 \mathrm{~g}$ ) were purchased from China Medical Primates Center, Kunming, China. None of the animals had evidence of antibodies against RVA and PV by neutralization test. Guinea pigs were housed in microisolation cages and all procedures were conducted in accordance with protocols approved by the Institute of Medical Biology Animal Care and Use Ethic Committee (approval No.: YISHENGLUNZI [2011] 15). Recombinant vector protein VP6F, chimeric protein $6 \mathrm{~F} /$ PV1N123, and reference strains RV Wa, PV1, PV2, PV3 were used as immunogens. Four guinea pigs were used for each immunogen inoculation. Guinea pigs in each group were immunized in the hind leg with $120 \mu \mathrm{g}$ of recombinant proteins in $100 \mu$ of dilution 
solution (15 mmol/l Tris; $150 \mathrm{mmol} / \mathrm{l} \mathrm{NaCl}$ [pH 7.0]). For RV Wa and PV1, PV2, PV3, $1 \times 10^{7} \mathrm{TCID}_{50}$ of the virus was administrated to each animal at each injection. At the same time, four guinea pigs were used as negative control and inoculated with $100 \mu \mathrm{l}$ of dilution solution. Each animal was inoculated three times at 0,14 and 28 days. Guinea pigs were bled by heart puncture at the fifth day after the last immunization. The blood samples were incubated at $37^{\circ} \mathrm{C}$ for $30 \mathrm{~min}, 4^{\circ} \mathrm{C}$ for $3 \mathrm{hr}$, and centrifuged at $8,000 \times \mathrm{g}$ at $4^{\circ} \mathrm{C}$ for $20 \mathrm{~min}$. Antibody levels were detected by Western blot and neutralization test.

Indirect immunofluorescence assay (IFA). To detect PV1 antigen, Vero cells were grown on glass coverslips and when confluent monolayers were attained, the cells were washed three times with phosphate buffered saline (PBS) and infected with PV1. The coverslips were taken out $12 \mathrm{hr}$ after infection, washed twice with PBS, fixed with pre-chilled methanol, and rehydrated at $4^{\circ} \mathrm{C}$ for $10 \mathrm{~min}$ with $70 \%, 30 \%$, and $10 \%$ of pre-chilled ethanol. After washing with PBS, coverslips were incubated for $1 \mathrm{hr}$ at $37^{\circ} \mathrm{C}$ with antisera against chimeric protein (1:400 dilution in $0.1 \%$ of bovine serum albumin). The unbound antibodies were removed by washing with PBST (PBS containing $0.2 \%$ Tween 20 ). The cells were then incubated at $37^{\circ} \mathrm{C}$ for $1 \mathrm{hr}$ with FITC-labeled goat anti-guinea pig IgG (1:100 dilution; Sigma, USA), followed by washing with PBST. Fluorescence was detected under microscope (Nikon Eclipse E600, Japan). Meanwhile, as controls, fluorescence analysis of noninfected cells with pre-inoculated sera, virus inoculated or negative (inoculated with PBS) guinea pig sera were carried out. To detect RV antigen, MA104 cells were infected with RV strain Wa, and immunofluorescence assay was performed as described above.

Western blot of chimeric protein. Expressed samples diluted in gel loading buffer ( $2 \mathrm{mmol} / \mathrm{l}$ EDTA, $50 \mathrm{mmol} / \mathrm{l}$ Tris [pH 6.8], 10\% glycerol, $1 \%$ SDS, $1 \% \beta$-mercaptoethanol, $0.05 \%$ bromophenol blue) were heated at $95^{\circ} \mathrm{C}$ for $5 \mathrm{~min}$, cooled at room temperature, and then subjected to SDS-PAGE. The separated proteins in the SDS-PAGE gel were blotted onto PVDF membranes for $20 \mathrm{~min}$ at $50 \mathrm{~V}$ using Trans-Blot SD semi-dry electrophoretic transfer cell (Bio-Rad Laboratories, USA). After blocking with 5\% skimmed milk in TBS (25 mmol/l Tris- $\mathrm{HCl}$ [pH 7.5], 0.9\% NaCl), the membranes were incubated with antiserum (1:400 dilution) from immunized guinea pigs. After washing with TBST $(0.1 \%$ Tween 20 in TBS), the membranes were incubated with goat anti-guinea pig IgG conjugated with horseradish peroxidase (1:2000 dilution; Sigma, USA). The membranes were washed and then incubated with 3,3'-diaminobenzidine tetrahydrochloride (DAB; Sigma, USA) to visualize bound antibodies.

Neutralization test. To determine the sera neutralization titer, a micro-neutralization assay was carried out. Briefly, $50 \mu \mathrm{l}$ of virus solution containing $100 \mathrm{TCID}_{50}$ was mixed with an equal volume of the guinea pig antisera at 2 -fold serial dilutions and incubated in a $5 \% \mathrm{CO}_{2}$ humidified incubator for $1 \mathrm{hr}$ at $37^{\circ} \mathrm{C}$. The mixture was then added onto cell monolayers in a 96 -well tissue culture plate with four replicates per dilution. The plates were further incubated at $37^{\circ} \mathrm{C}$ in a humidified $\mathrm{CO}_{2}$ incubator for $48 \mathrm{hr}$ and regularly ob-

served for CPE presence. The appropriate cell and serum controls were included for each plate. Neutralizing titers were defined as the reciprocal of the highest dilution of antiserum that protected $50 \%$ of cells from virus-associated CPE.

\section{Results}

Expression of chimeric protein in E. coli

Three epitopes PV1N1, PV1N2, and PV1N3 of PV1 were introduced together into VP6F. The recombinant plasmid, designated as pETP6F/PV1N123, was confirmed by sequencing and then transformed into competent BL21 (DE3) cells for expression. The plasmid pETP6F was used as a control. The expressed chimeric protein $6 \mathrm{~F} / \mathrm{PV} 1 \mathrm{~N} 123$ carrying epitopes PV1N1, PV1N2, and PV1N3 of PV1 was approximately $48 \mathrm{kDa}$ (Fig. 2a,b, lane 2 ), and the vector protein VP6F was about $43.2 \mathrm{kDa}$ (Fig. 2a,b, lane 1) as expected. The expressed proteins were retained in precipitate after sonication, indicating 6F/PV1N123 and VP6F were mainly in the form of inclusion bodies.

\section{Immunoreactivity of chimeric protein}

The immunological reactivity of the chimeric protein was detected by Western blot. Western blot results showed that the chimeric protein could be specifically recognized

(a)

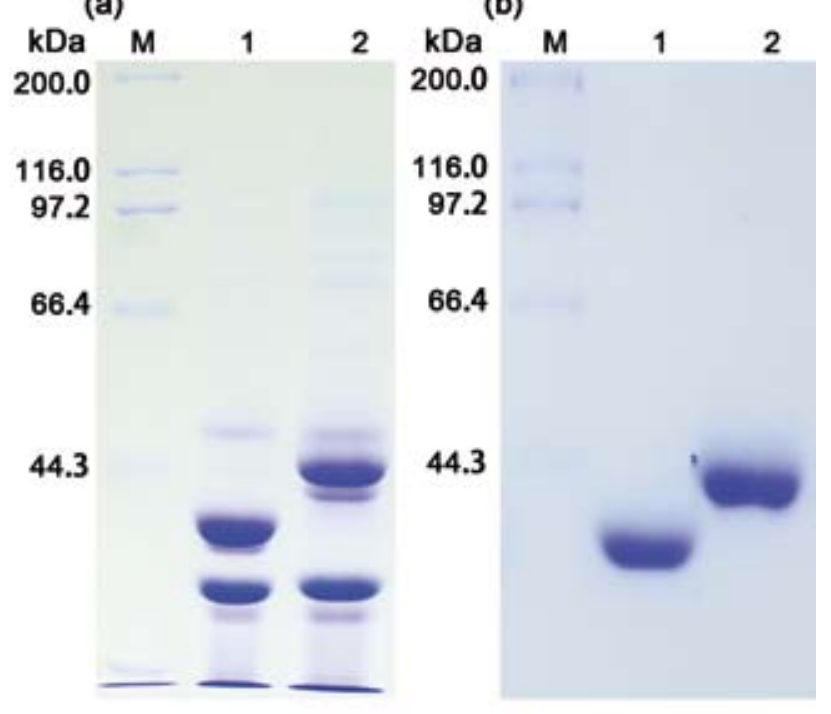

Fig. 2

$10 \%$ SDS-PAGE of recombinant chimeric protein before (a) and after purification (b)

Lane M: Protein molecular weight standard $(\mathrm{kDa})$; lane 1: vector protein VP6F; lane 2: chimeric protein 6F/PV1N123. 
(a)

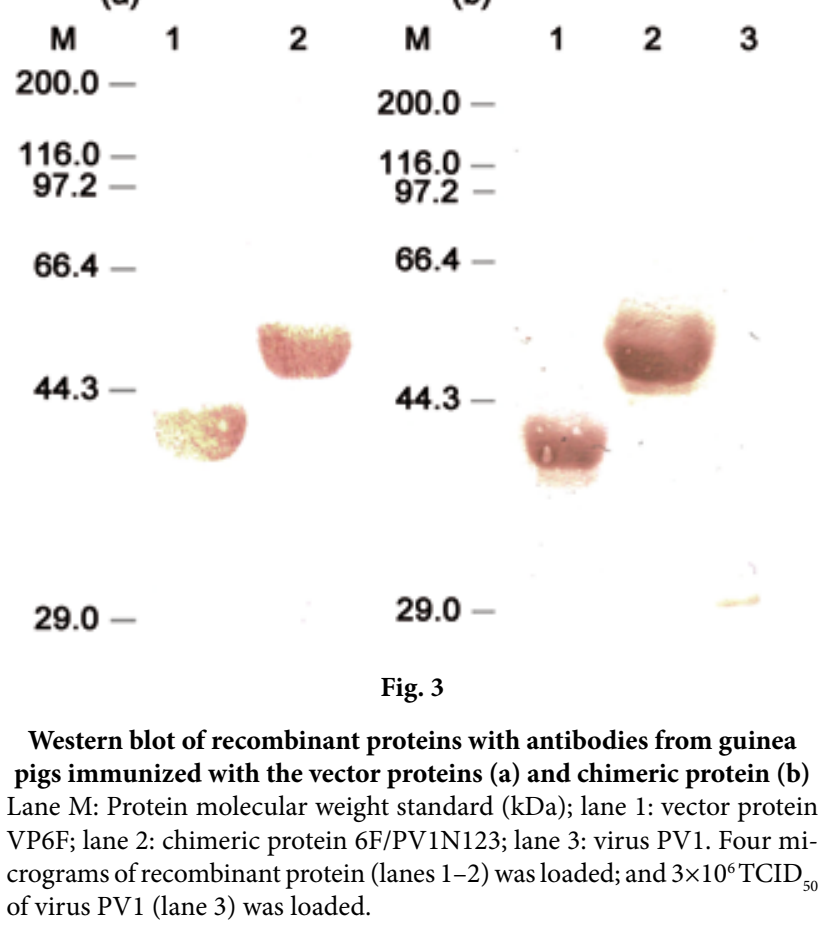

by antibodies derived from guinea pigs inoculated with vector protein VP6F (Fig. 3a). There was no immunoreactivity of sera derived from pre-immune or negative control animals observed with VP6F or the chimeric protein (data not shown).

The antibodies derived from guinea pigs immunized with chimeric protein both reacted with the vector protein VP6F and chimeric protein 6F/PV1N123 (Fig. 3b). The VP1 but not VP2 or VP3 protein of PV1 could be recognized by the antibodies from guinea pigs immunized with the chimeric protein (Fig. 3b, lane 3).

\section{IFA of PV1 antigen in PV1 infected Vero cells}

PV antigen synthesized in PV1 infected Vero cells and RV antigen synthesized in RV Wa infected MA104 cells were detected by IFA (Fig. 4). The results showed that PV1 antigen in PV1 infected Vero cells could be detected by antibodies from guinea pigs inoculated with PV1 (Fig. 4a), and chimeric protein 6F/PV1N123 (Fig. 4c). No fluorescence was detected in PV1 infected cells when detected with antibodies against the vector VP6F (Fig. 4b), and pre-inoculation sera (Fig. 4d). RV antigen in RV Wa infected MA104 cells could be detected by antibodies against VP6F (Fig. 4f), and chimeric protein 6F/PV1N123 (Fig. 4g). No fluorescence was detected in RV Wa infected cells with antibodies against PV1 (Fig. 4e), PV2 or PV3 (data not shown), mock inoculated or pre-inoculation sera (Fig. 4h).

\section{Neutralizing antibody activity}

Neutralization test has been applied to examine the sensitivity of virus-specific antibodies produced in tested animals, or the reduction of infectious units of the RV and PV. Results showed that antibodies against the chimeric protein neutralized infection of RV and PV1, in MA104 and Vero cells, respectively (Table 2).

Using PV and RV Wa as infection viruses, the neutralizing titers in antisera against the chimeric protein $6 \mathrm{~F} / \mathrm{PV} 1 \mathrm{~N} 123$ were 1:320 against Wa infection, and 1:400 against PV1 infection (Table 2). No neutralizing activity against PV1 infection was detected in antisera from guinea pigs inoculated with vector protein VP6F (lower than 1:4), and no neutralizing activity against PV1 or RV infections was detected in antisera from guinea pigs mock-inoculated with PBS as negative control (lower than 1:4). In addition, no neutralizing activities were detected in all sera from all the guinea pigs used in this study when PV2 or PV3 were used as infection viruses (lower than 1:4).

\section{Discussion}

Despite the decrease of RV and PV infections due to efficient use of inactivated and live attenuated vaccines, both diseases still remain important public health problem in some areas. In recent years, research and development of chimeric protein vaccines which were used to overcome some concerns that exist in live attenuated virus vaccines has made a great progress. It has been demonstrated that if a foreign epitope was inserted in an appropriate position on the vector protein, the chimeric protein could elicit antibodies that recognized the vector protein and neutralize the infection by the epitope-derived virus (Teng et al., 2014; Tisminetzky et al., 1994). In this study, a chimeric protein-based vaccine that could simultaneously prevent both RV and PV infection was designed and produced. Three neutralizing epitopes derived from the VP1 of PV1 were inserted into the surface of VP6F. The insertion sites were chosen in three different outer loops on the surface of VP6F. Results showed that the chimeric protein had specific immunogenicity and could elicit high antibody titers against both RV and PV1 in guinea pigs, suggesting that the chimeric protein based on the VP6F vector system may be a useful vaccine approach for the multimeric presentation of immunogenic epitopes.

RV VP6, as a highly immunogenic and the most significant immunodiagnostic protein for RVA detection (Svensson et al., 1987), shares a high degree of antigenic cross-reactivity and could potentially provide heterotypic protection from RV infection. In recent years, the VP6 became a hot topic as it was studied in attempts to develop VP6-based vaccines, and some studies demonstrated that antibodies directed to 
(a)

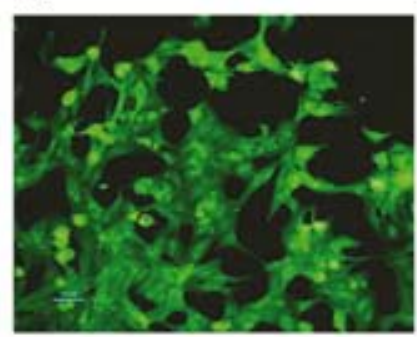

(e)

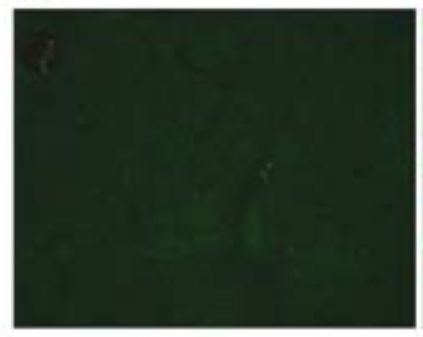

(b)

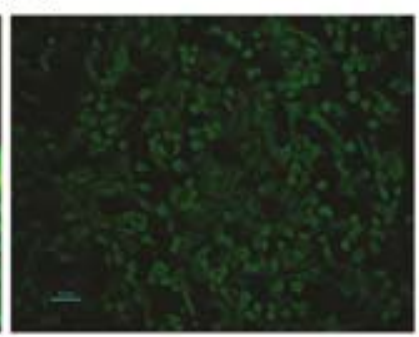

(f)

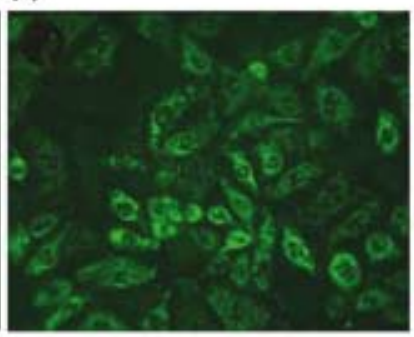

(c)

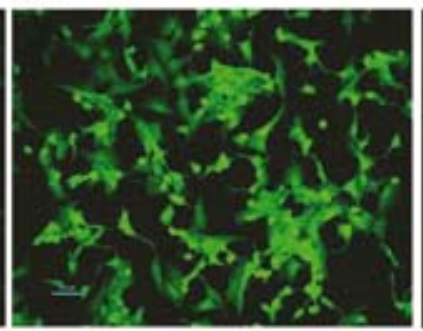

(g)

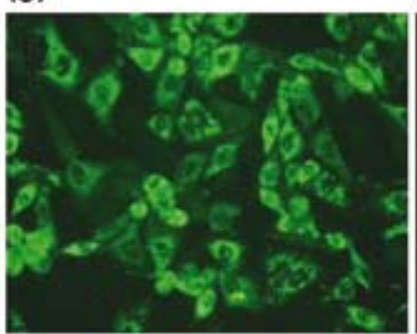

(d)

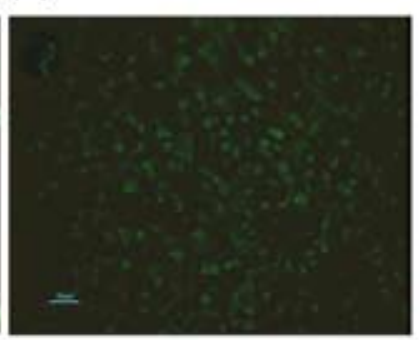

(h)

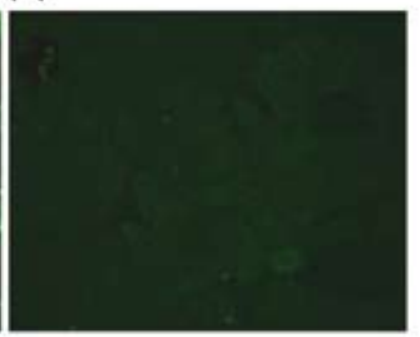

Fig. 4

Immunofluorescence analysis

VP1 antigen in PV1 infected Vero cells detected with antibodies from guinea pigs inoculated with PV1 (a), vector protein VP6F (b), chimeric protein 6F/ PV1N123 (c), mock inoculated with PBS (d); and RV antigen in RV Wa infected MA104 cells detected with antibodies from guinea pigs inoculated with PV1 (e), vector protein VP6F (f), chimeric protein 6F/PV1N123 (g) and mock inoculated with PBS (h). Bar: $50 \mu \mathrm{m}(\mathrm{a}-\mathrm{d}), 20 \mu \mathrm{m}(\mathrm{e}-\mathrm{h})$.

VP6 possess broad neutralizing activity in vitro and confer protection against diarrhea in mice (Garaicoechea et al., 2008) and neonatal gnotobiotic piglets (Vega et al., 2013).

In previous study a foreign epitope-presenting system using the RV VP6 as a vector was constructed (Teng et al., 2014). The molecular structure of VP6F showed that the bone structure of VP6 was fully maintained, and the six foreign epitope insertion sites, designated I1, I2, I3, I4, I5 and I6, were as expected on exposed surface. In this study, using this vector protein, three highly conserved epitopes derived from the PV1 were selected, and inserted into epitope insertion sites I1, I3 and I5. The results demonstrated that these epitopes presented in this form could cross-react with anti-VP6F and anti-PV1 antibodies. Antibodies against the chimeric protein could react with VP6F and VP1 of PV1 and neutralize both $\mathrm{RV}$ strain Wa and PV1 infection in vitro.
The epitopes of PV and the VP6 of RV are both highly conserved in different genotypes of the PV and RV respectively (Kitamura and Wimmer, 1980; Matthijnssens et al., 2012). Results showed that the recombinant chimeric protein 6 F/PV1N123 could react with antibodies against VP6F and PV1, and induce production of neutralizing antibodies in animals. The antibody against chimeric protein could recognize VP1 antigen in PV1 infected cells, implying that the conformational structure of the epitopes remains in the infected cells. Cross neutralizing antibodies against the chimeric protein could neutralize infections by RV and PV1 in vitro, implying that the chimeric protein may be used as a candidate epitope-based vaccine. However, only epitopes derived from PV1 were included in the chimeric protein, the chimeric proteins carrying epitopes from other serotypes of the PV should be further addressed. In addition, virus-

Table 2. Neutralization titers of antibodies from chimeric protein carrying PV1 epitopes inoculated guinea pigs

\begin{tabular}{lccccccc}
\hline & \multicolumn{5}{c}{ Neutralization titer of antibody $^{*}$} \\
\cline { 2 - 7 } Virus & NC $^{* *}$ & VP6F & 6F/PV1N123 & PV1 & PV2 & PV3 \\
\hline PV1 & $<4$ & $<4$ & 400 & 10240 & $<4$ & $<4$ \\
PV2 & $<4$ & $<4$ & $<4$ & $<4$ & $<4$ & 10240 & $<4$ \\
PV3 & $<4$ & $<4$ & 320 & $<4$ & $<4$ & $<4$ \\
Wa & $<4$ & 320 & $<4$ & $<4$ & $<4$ \\
\hline
\end{tabular}

*Arithmetic mean NT titers; ${ }^{*} \mathrm{NC}$, negative control. In this group, sera were derived from animals that were pre-immune or mock immunized with PBS. Neutralizing titers are defined as the reciprocal of the highest dilution of antiserum that protected $50 \%$ of cells from virus-associated CPE. 
like particles should be produced in order to further study the evaluation of the effectiveness of the combined vaccine candidates. Anyway, this VP6-based epitope presenting system and the recombinant VP6-based PV epitope chimeric protein will be valuable for the development of a novel RV/ $\mathrm{PV}$ chimeric vaccine and vaccine vector.

Acknowledgements. This work was supported by grants from the Natural Science Foundation of China (No. 81460553) and Natural Scientific Fund of Yunnan Province (No. 2012FD039 and No. 2013FZ130).

\section{References}

Bannwarth L, Girerd-Chambaz Y, Arteni AA, Guigner JM, Lemains J, Ronzon F, Manin C, Vénien-Bryan C (2015): Structural studies of virus-antibody immune complexes (poliovirus type I): Characterization of the epitopes in 3D. Mol. Immunol. 63, 279-286. http://dx.doi.org/10.1016/j. molimm.2014.07.014

Blondel B, Crainic R, Fichot O, Dufraisse G, Candrea A, Diamond D, Girard M, Horaud F (1986): Mutations conferring resistance to neutralization with monoclonal antibodies in type 1 poliovirus can be located outside or inside the antibody-binding site. J. Virol. 57, 81-90.

Bugli F, Caprettini V, Cacaci M, Martini C, Paroni Sterbini F, Torelli R, Della Longa S, Papi M, Palmieri V, Giardina B, Posteraro B, Sanguinetti M, Arcovito A (2014): Synthesis and characterization of different immunogenic viral nanoconstructs from rotavirus VP6 inner capsid protein. Int. J. Nanomedicine 9, 2727-2739.

Chen Y, Xiong X, Liu X, Li J, Wen Y, Chen Y, Dai Q, Cao Z, Yu W (2006): Immunoreactivity of HCV/HBV epitopes displayed in an epitope-presenting system. Mol. Immunol. 43, 436-442. http://dx.doi.org/10.1016/j. molimm.2005.03.002

Chumakov K, Ehrenfeld E (2008): New generation of inactivated poliovirus vaccines for universal immunization after eradication of poliomyelitis. Clin. Infect. Dis. 47, 1587-1592. http://dx.doi.org/10.1086/593310

Cunliffe NA, Witte D, Ngwira BM, Todd S, Bostock NJ, Turner AM, Chimpeni P, Victor JC, Steele AD, Bouckenooghe A, Neuzil KM (2012): Efficacy of human rotavirus vaccine against severe gastroenteritis in Malawian children in the first two years of life: a randomized, double-blind, placebo controlled trial. Vaccine 30, 36-43. http://dx.doi. org/10.1016/j.vaccine.2011.09.120

Diamond DC, Jameson BA, Bonin J, Kohara M, Abe S, Itoh H, Komatsu T, Arita M, Kuge S (1985): Antigenic variation and resistance to neutralization in poliovirus type 1 . Science 229, 1090-1093. http://dx.doi.org/10.1126/science.2412292

El-Senousy WM, Shahein YE, Barakat AB, Ghanem HE, El-Hakim AE, Ameen SM (2013): Molecular cloning and immunogenicity evaluation of rotavirus structural proteins as candidate vaccine. Int. J. Biol. Macromol. 59, 67-71. http://dx.doi.org/10.1016/j.ijbiomac.2013.04.003
Eng PM, Mast TC, Loughlin J, Clifford CR, Wong J, Seeger JD (2012): Incidence of intussusception among infants in a large commercially insured population in the United States. Pediatr. Infect. Dis. J. 31, 287-291. http://dx.doi. org/10.1097/INF.0b013e31824213b1

Fiore L, Ridolfi B, Genovese D, Buttinelli G, Lucioli S, Lahm A, Ruggeri FM (1997): Poliovirus Sabin type 1 neutralization epitopes recognized by immunoglobulin A monoclonal antibodies. J. Virol. 71, 6905-6912.

Garaicoechea L, Olichon A, Marcoppido G, Wigdorovitz A, Mozgovoj M, Saif L, Surrey T, Parreo V (2008): Llama-derived single-chain antibody fragments directed to rotavirus VP6 protein possess broad neutralizing activity in vitro and confer protection against diarrhea in mice. J. Virol. 82, 9753-9764. http://dx.doi.org/10.1128/JVI.00436-08

Giammarioli AM, Mackow ER, Fiore L, Greenberg HB, Ruggeri FM (1996): Production and characterization of murine IgA monoclonal antibodies to the surface antigens of Rhesus rotavirus. Virology 225, 97-110. http://dx.doi. org/10.1006/viro.1996.0578

Hagan JE, Wassilak SG, Craig AS, Tangermann RH, Diop OM, Burns CC, Quddus A, Centers for Disease Control and Prevention (2015): Progress toward polio eradicationworldwide, 2014-2015. MMWR Morb. Mortal. Wkly. Rep. 64, 527-531.

Herremans T, Reimerink JH, Kimman TG, van Der Avoort HG, Koopmans MP (2000): Antibody responses to antigenic sites 1 and 3 of serotype 3 poliovirus after vaccination with oral live attenuated or inactivated poliovirus vaccine and after natural exposure. Clin. Diagn. Lab. Immunol. 7, 40-44. http://dx.doi.org/10.1128/cdli.7.1.40-44.2000

Hogle JM, Filman DJ (1989): The antigenic structure of poliovirus. Phil. Trans. R. Soc. Lond. B 323, 467-478. http://dx.doi. org/10.1098/rstb.1989.0024

Kitamura N, Wimmer E (1980): Sequence of 1060 3'-terminal nucleotides of poliovirus RNA as determined by a modification of the dideoxynucleotide method. Proc. Natl. Acad. Sci. USA 77, 3196-3200. http://dx.doi.org/10.1073/ pnas.77.6.3196

Kollaritsch H, Kundi M, Giaquinto C, Paulke-Korinek M (2015): Rotavirus vaccines: a story of success. Clin. Microbiol. Infect. 21, 735-743. http://dx.doi.org/10.1016/j. cmi.2015.01.027

Li T, Lin H, Zhang Y, Li M, Wang D, Che Y, Zhu Y, Li S, Zhang J, Ge S, Zhao Q, Xia N (2014): Improved characteristics and protective efficacy in an animal model of E. coli-derived recombinant double-layered rotavirus virus-like particles. Vaccine 32, 1921-1931. http://dx.doi.org/10.1016/j. vaccine.2014.01.093

Lowry OH, Rosebrough NJ, Farr AL, Randall RJ (1951): Protein measurement with the folin phenol reagent. J. Biol. Chem. 193, 265-275.

Marashi SM, Jalilvand S, Mollaei-Kandelous Y, Shahmahmoodi S, Rezaei F, Salimi V, Nejati A, Validi M, Shoja Z (2014): Intra-peritoneal and intra-rectal immunogenicity induced by rotavirus virus like particles $2 / 6 / 7$ in mice. $\mathrm{Mi}$ crob. Pathog. 67-68, 48-54. http://dx.doi.org/10.1016/j. micpath.2014.02.005 
Matthijnssens J, Otto PH, Ciarlet M, Desselberger U, Van Ranst M, Johne R (2012): VP6-sequence-based cut off values as a criterion for rotavirus species demarcation. Arch. Virol. 157, 1177-1182. http://dx.doi.org/10.1007/s00705$\underline{012-1273-3}$

Minor PD, Schild GC, Bootman J, Evans DM, Ferguson M, Reeve P, Spitz M, Stanway G, Cann AJ. Hauptmann R, Clarke LD, Mountford RC, Almond JW (1983): Location and primary structure of a major antigenic site for poliovirus neutralization. Nature 301, 674-679. http://dx.doi. org/10.1038/301674a 0

Minor PD, Ferguson M, Evans DMA, Almond JW, Icenogle JP (1986): Antigenic structure of poliovirus of serotypes 1, 2, and 3. J. Gen. Virol. 67, 1283-1291. http://dx.doi. org/10.1099/0022-1317-67-7-1283

Ogra PL, Kartzon DT (1971): Formation and function of poliovirus antibody in different tissues. Prog. Med. Virol. 13, 641-650.

Page GS, Mosser AG, Hogle JM, Filman DJ, Rueckert RR, Chow M (1988): Three-dimensional structure of poliovirus serotype 1 neutralizing determinants. J. Virol. 62, 1781-1794.

Parashar UD, Gibson CJ, Bresse JS, Glass RI (2006): Rotavirus and severe childhood diarrhea. Emerg. Infect. Dis. 12, 304-306. http://dx.doi.org/10.3201/eid1202.050006

Pastor AR, Rodriguez-Limas WA, Contreras M, Esquivel E, Esquivel-Guadarrama F, Ramírez OT, Palomares LA (2014): The assembly conformation of rotavirus VP6 determines its protective efficacy against rotavirus challenge in mice. Vaccine 32, 2874-2877. http://dx.doi.org/10.1016/j. vaccine. 2014.02 .018

Reed LJ, Muench H (1938): A simple method of estimating fifty percent end points. Am. J. Epidemiol. 27, 493-497.

Roberts L (2014): Just one poliovirus left to go? Science 346, 795. http://dx.doi.org/10.1126/science.346.6211.795

Savilahti E, Klemola T, Carlsson B, Mellander L, Stenvik M, Hovi T (1988): Inadequacy of mucosal IgM antibodies in selective IgA deficiency: excretion of attenuated polio viruses is prolonged. J. Clin. Immunol. 8, 89-94. http://dx.doi. org/10.1007/BF00917895

Shoja Z, Tagliamonte M, Jalilvand S, Mollaei-Kandelous Y, De Stradis A, Tornesello ML, Buonaguro FM, Buonaguro L (2015): Formation of self-assembled triple-layered rotavirus-like particles (tlRLPs) by constitutive co-expression of VP2, VP6, and VP7 in stably transfected high-five insect cell lines. J. Med. Virol. 87, 102-111. http://dx.doi. org/10.1002/jmv.23973

Sow SO, Tapia M, Haidara FC, Ciarlet M, Diallo F, Kodio M, Doumbia M, Dembélé RD, Traoré O, Onwuchekwa UU, Lewis KD, Victor JC, Steele AD, Neuzil KM, Kotloff KL, Levine MM (2012): Efficacy of the oral pentavalent ro- tavirus vaccine in Mali. Vaccine 30, 71-78. http://dx.doi. org/10.1016/j.vaccine.2011.11.094

Steele AD, De Vos B, Tumbo J, Reynders J, Scholtz F, Bos P, de Beer MC, Van der Merwe CF, Delem A (2010): Coadministration study in South African infants of a liveattenuated oral human rotavirus vaccine (RIX4414) and poliovirus vaccines. Vaccine 28, 6542-6548. http://dx.doi. org/10.1016/j.vaccine.2008.08.034

Svensson L, Sheshberadaran H, Vesikari T, Norrby E, Wadell G (1987): Immune response to rotavirus polypeptides after vaccination with heterologous rotavirus vaccines (RIT 4237, RRV-1). J. Gen. Virol. 68, 1993-1999. http://dx.doi. org/10.1099/0022-1317-68-7-1993

Tate JE, Burton AH, Boschi-Pinto C, Steele AD, Duque J, Parashar UD, WHO-coordinated Global Rotavirus Surveillance Network (2012): 2008 estimate of worldwide rotavirusassociated mortality in children younger than 5 years before the introduction of universal rotavirus vaccination programmes: a systematic review and meta-analysis. Lancet Infect. Dis. 12, 136-141. http://dx.doi.org/10.1016/ $\underline{\text { S1473-3099(11)70253-5 }}$

Teng Y, Zhao B, Pan X, Wen Y, Chen Y (2014): A new rotavirus VP6based foreign epitope presenting vector and immunoreactivity of VP4 epitope chimeric proteins. Viral. Immunol. 27, 96-104. http://dx.doi.org/10.1089/vim.2013.0110

Tisminetzky SG, Scodeller EA, Evangelisti P, Chen Y, Schiappacassi M, Porro F, Bizik F, Zacchi T, Lunazzi G, Miertus S, Baralle FE (1994): Immunoreactivity of chimeric proteins carrying the HIV-1 epitope IGPGRAF: conformation and antigenicity. FEBS Lett. 353, 1-4. http://dx.doi. org/10.1016/0014-5793(94)00972-4

Van der Marel P, Hazendonk TG, Henneke MA, van Wezel AL (1983): Induction of neutralizing antibodies by poliovirus capsid polypeptides VP1, VP2, and VP3. Vaccine 1, 1722. http://dx.doi.org/10.1016/0264-410X(83)90007-5

Vega CG, Bok M, Vlasova AN, Chattha KS, Gómez-Sebastián S, Nuez C, Alvarado C, Lasa R, Escribano JM, Garaicoechea LL, Fernandez F, Bok K, Wigdorovitz A, Saif LJ, Parre-o V (2013): Recombinant monovalent llama-derived antibody fragments ( $\mathrm{VHH}$ ) to rotavirus VP6 protect neonatal gnotobiotic piglets against human rotavirus-induced diarrhea. PLoS Pathog. 9, e1003334. http://dx.doi.org/10.1371/journal.ppat.1003334

Zaman K, Sack DA, Yunus M, Arifeen SE, Podder G, Azim T, Luby S, Breiman RF, Neuzil K, Datta SK, Delem A, Suryakiran PV, Bock HL, Bangladeshi Rotavirus Vaccine study group (2009): Successful co-administration of a human rotavirus and oral poliovirus vaccines in Bangladeshi infants in a 2-dose schedule at 12 and 16 weeks of age. Vaccine 27, 1333-1339. http://dx.doi.org/10.1016/j. vaccine.2008.12.059 